\title{
An exploration of the techniques, outputs and outcomes of circulation management at exhibitions
}

\author{
Sabine Töppig \\ Miguel Moital * \\ Bournemouth University \\ Department of Sport \& Events Management \\ Bournemouth University Business School \\ United Kindgom \\ Emails: mmoital@bournemouth.ac.uk/sabine_toeppig@hotmail.de
}

* Corresponding author. Address: Dorset House, Talbot Campus, Fern Barrow, BH12 5BB, United Kingdom; telephone +441202966674

\section{Please cite as:}

Töppig, S. and Moital, M., An exploration of the techniques, outputs and outcomes of circulation management at exhibitions, International Journal of Event and Festival Management, forthcoming.

\begin{abstract}
Purpose - To establish how and why exhibition managers manage circulation, this study explores the techniques (specific activities used to influence circulation), outputs (tangible enhancements in the performance of the exhibition resulting from changes in circulation dynamics), and outcomes (benefits of those enhancements to exhibitors, attendees and the exhibition organiser) of circulation management.

Design/methodology/approach - In face-to-face interviews, ten exhibition managers were asked how and why they manage attendee circulation, which also involved a card-sorting exercise to elicit tacit circulation management knowledge. Four different experienced exhibitions managers from three continents were asked to validate the findings.

Findings - Four types of techniques were identified: magnet, layout, curiosity \& playfulness and guiding techniques, with these implemented to achieve five outputs: greater footfall, better exposure to exhibits, enhanced navigation, greater buzz, and managing congestion levels. The results further show that circulation was managed to achieve a variety of organiser-, exhibitorand attendee-related outcomes. The study uncovered a large range of factors influencing the employment of circulation management techniques. Conflicts in outputs resulting from several techniques are highlighted, requiring the exhibition manager to establish which outputs and resulting outcomes take priority over others.
\end{abstract}

Originality/value - This exploratory study is the first study to propose a circulation management model for the exhibition context, equipping exhibition managers with knowledge to strategically manage attendee circulation.

Keywords: Circulation management, Exhibitions, Techniques, Outputs, Outcomes 


\section{Introduction}

Exhibitions, also frequently called expositions, trade shows or trade fairs (Whitfield and Webber, 2011), are "recurrent business events that facilitate various forms of commercial and social exchanges among key stakeholders" (Tafesse and Skallerud, 2017, p. 19). Exhibitions can be entities of their own and therefore booth-led, with the focus being on showcasing products and services, or take place as part of conferences and congresses and be content-led, where the focus for attendees often lies in learning from content delivered by speakers. According to the Business Visits and Events Partnership (BVEP), the UK's exhibition sector is worth $£ 11$ billion and is therefore the second-strongest contributor to the event industry's worth, after conferences and meetings (BVEP, 2017). Due to the business networking nature of exhibitions, they play an important role in strengthening business ties by bringing together government officials, businesses and consumers that otherwise would find it difficult to interact on a face-to-face basis (Qi et al., 2018).

Due to this significant economic impact generated by exhibitions, researchers from different fields, notably events but also tourism (e.g. Rittichainuwat and Mair, 2012), marketing (Adams et al., 2017) and computer science (e.g. Chung et al., 2014), have sought to extend our understanding of the industry. A large proportion of exhibition studies examines exhibitors and their participation in exhibitions (Lee and Kang, 2014; Lee and Lee, 2014), such as their motivations (Lee et al., 2010; Chung et al., 2014), satisfaction (Lin et al., 2018), exhibition selection criteria (Kijewski et al., 1993) and evaluation of service design elements (Lin and Lin, 2013). A number of studies have sought to understand visitor decision-making and behaviour towards exhibitions, such as their motivation (e.g. Lee et al., 2010), satisfaction (Lin et al., 2018) and attachment (Yi et al., 2018). The organiser's perspective has been much less researched. Some exceptions include a study profiling the stages of new service development for new trade shows (Bauer and Borodako, 2019), a study on the factors that exhibition organizers look for when selecting venues (Lee and Lee, 2017) and a study on the drivers and inhibitors to successful customer relationship management in exhibitions (Wang et al., 2014).

Given the above, it is not surprising that there have been calls for more organiser-focussed studies to be carried out (Tafesse and Skallerud, 2017). This paper responds to this call by looking at circulation management, which, to date, remains unresearched. Exhibition organisers intend to generate revenue from staging exhibitions, more specifically from selling tickets, exhibition space and sponsorship (Frost and Laing, 2018). Their main objective is "to create highly effective shows that result in positive outcomes for both exhibitors and visitors", because they translate into success for the organiser (Vaid et al., 2016, p. 72). This interdependency of individual stakeholders' success indicates that it is important for exhibition managers to know how to achieve the best possible results for their stakeholders, and ultimately themselves. The achievement of these interdependent results drives the conceptualisation of the exhibition space. Originally an empty space, exhibition organisers carefully plan the exhibition, considering many components of product design, one of which is circulation. Circulation, defined as "the movement of visitors through a three-dimensional space" (Hughes, 2010, p. 218), determines whom and what attendees encounter and interact with at an exhibition (Bitgood, 2006). This interaction is vital for generating value for exhibitors and attendees (Rossen and Seringhaus, 1995), emphasising the importance of adequate circulation.

In order to develop an understanding of circulation management within exhibitions, this paper explores how and why (to what end) circulation is managed, more specifically, the techniques, outputs and outcomes employed by exhibition managers. A technique "is a particular trick, 
stratagem, or contrivance used to accomplish an immediate objective" (Anthony, 1963, p. 66), that is, the manifest actions performed by exhibition managers to influence circulation. Outputs are the immediate, often tangible effects resulting from techniques (Parsons et al., 2013) representing the intermediary step towards outcomes (De Kruijf and de Vries, 2018). In this paper, they refer to the tangible enhancements in the performance of the exhibition resulting from changes in circulation dynamics. Outcomes, in turn, are the often less tangible end-results of outputs, more specifically the intermediate and long-term changes resulting from techniques and their outputs (De Kruijf and de Vries, 2018). In this paper, they refer to the benefits to participants, exhibitors and the exhibition organiser caused by the improved circulation performance. Exploring techniques, outputs and outcomes provides an in-depth understanding of each individual element in the circulation management process, while exploring their relationship allows understanding circulation management as a whole. Understanding the cascading effects of action on results is valuable to exhibition managers as it can inform the strategic employment of circulation management techniques.

\section{Literature review}

Circulation literature has focused on two key research streams: circulation patterns and circulation management. Research into circulation patterns encompasses three sub-streams: the first sub-stream is concerned with evaluating methods to collect circulation data, e.g. using observation (e.g. Yalowitz and Bronnenkant, 2009) or modern tracking technologies (e.g. Chongwatpol, 2015; Angel, 2019). The second sub-stream involves the identification of dominant movement patterns, e.g. the right-turn-bias or exit-gradient-theory (Melton, 1935). Studies belonging to the final sub-stream examine the origin of these movement patterns. Some argue they originate within the individual, and that circulation is determined by visitor agendas, such as cultural backgrounds (Dejbakshs et al., 2011), while others argue that movement patterns are the result of the configuration of space (Hillier et al., 1993), or a consolidation of both perspectives (Bitgood, 2006).

The second key stream of research explores circulation management, where this paper sits. Circulation management, in essence, involves strategically employing techniques to counteract dominant movement patterns and achieve intended results. To establish what is known about circulation management, more specifically how and why circulation is managed, the literature belonging to this research stream is next reviewed in terms of techniques, outputs and outcomes. Given that the exhibition literature to date focusses on establishing best practice for tracking attendee movement rather than influencing it, and that there is a substantial body of research on circulation management outside the exhibitions literature (retail, shopping centres, visitor attractions), the review of outcomes, outputs and techniques starts with a review of this wider literature. Next, the exhibition industry-context literature is reviewed, including material from both the academic and industry spheres. The use of non-academic sources is warranted by the fact that it provides insights into circulation management on the operational level, including practical examples, therefore making an important contribution to the existing body of knowledge of circulation management within exhibitions. Outcomes are reviewed first, followed by outputs and techniques because this facilitates discussion of the reasoning behind the use of techniques.

\subsection{Outcomes}

Outcomes can be either consumer- or organisation-centred. Organisation-centred outcomes benefit the organisation running the premises within which circulation is managed. For example, in retail, circulation is managed to increase store profits by increasing consumers' 
exposure to products (Granbois, 1968). In shopping centres, it maximises rental profits. The objective of shopping centre design is to create evenly-balanced footfall to all tenants rather than merely those who can afford locations with naturally high footfall (Fahmy et al., 2014) because the amount of rent charged is generally related to store profits (Shanmugam, 2013). In the context of cultural heritage, circulation management allows the limitation of damages to sites and thus their conservation (Enseñat-Soberanis et al., 2019).

Organisational outcomes are closely related to consumer outcomes, because visitor satisfaction can induce behaviours which are desirable for the organisation, e.g. intention to return and recommending to others (Bitgood, 1988). Thus, circulation research examines how to achieve desirable consumer outcomes, e.g. increased convenience (Uotila and Skogster, 2007), attention (Bitgood, 2009; Antón et al., 2018), enjoyment from experiencing and being exposed to interesting exhibits or sights (Y1lmazsoy, 2005) and enhanced tourist experiences (Zubiaga et al., 2019). Additionally, circulation is managed to avoid negative consumer outcomes, e.g. stress (Robillard, 1982), confusion (Fitch and Knobel, 1990), frustration, angst (Sorensen, 2009) and dissatisfaction from congestion (Zhang et al., 2017).

Following the review of outcomes within the wider literature, a look into exhibition literature revealed its predominant concern with achieving financial outcomes for exhibitors. Practitioner literature discusses circulation management as a means to making exhibitors' attendance profitable (Champagne, 2015), which generates beneficial outcomes for the organiser such as exhibitor happiness (Zhou, 2016). EventMB (2017) points out that exhibitors' dissatisfaction decreases their likelihood to return, therefore linking exhibitor and organiser outcomes. Rinallo et al. (2010) refer to circulation management as a generator of consumer outcomes, specifically satisfaction and absence of fatigue, due to facilitating attendees' search for information, a main reason for attending (Smith et al., 2003). Nonetheless, the combination of findings implies that circulation management is predominantly considered a tool to achieve exhibitor outcomes, not viewing consumer and organiser outcomes as important, unlike other research contexts.

\subsection{Outputs}

Outside the exhibition context, three circulation management outputs were identified. First, some are concerned with the avoidance of negative outputs. For example, disorientation leads to exhibits or entire exhibition spaces being missed (Y1lmazsoy, 2005) while increasing the risk of boredom and satiation, due to which the engagement with exhibits decreases over the course of the visit (Antón et al., 2018). Secondly, circulation management is employed to achieve maximum coverage of space and maximise the interface between consumer and product (Brown, 1991). Conversely, consumers only partially covering spaces limits the exposure of products or artefacts, a problem identified in museums (Klein, 1993) and retail (Sorensen, 2003). By contrast, cultural heritage sites employ circulation management to limit visitors to using the designated paths, in order to prevent damage to the sites (Enseñat-Soberanis et al., 2019). The third output, reduced congestion, dominates theme park circulation research. In order to maximise capacities, congestion is reduced through evenly redistributing visitors, which otherwise results in increased waiting times and disruption (Ahmadi, 1997; Zhang et al., 2017). Redistribution is also important in tourism in order to minimise its effects on the local community and increase the quality of the tourist experience (Zubiaga et al., 2019).

While reviewing the wider literature resulted in the identification of three outputs, exhibition literature focusses on two circulation outputs, the first being footfall. Exhibition organisers want to ensure sufficient footfall for exhibitors who are their clients (Hart, 2014), because exhibitors measure exhibition effectiveness partly by the attraction power of their stand (Bloch et al., 
2017). The second output, maximum coverage of the space, which was also identified in other contexts, is closely linked with the first. Exhibition organisers want to ensure that all areas of the exhibition gain exposure by increasing the amount of space attendees cover. They are particularly concerned with ensuring the absence of 'cold zones', areas with minimal footfall (EventMB, 2017).

\subsection{Techniques}

The literature on circulation management has identified a large number of techniques that can be employed by exhibition managers. These can be broadly classified into four categories: magnet, layout, guiding, and curiosity and playfulness techniques.

The first category relies on the notion that consumers are attracted by 'magnets', i.e. entities assumed to be of interest to a majority (e.g. Granbois, 1968; Shanmugam, 2013) which draw consumers to desired places (Fitch and Knobel, 1990). Magnets differ depending on the environment in which they are employed. In shopping centres, department stores, supermarkets or large chains typically assume the role of the 'magnet' or 'anchor' (Beddington, 1982), while moving attractions such as magicians and hypnotists are magnets in theme parks. One other important magnet is open space (Sorensen, 2009), which is achieved through the employment of layout techniques. Widening aisles and slanted shelves, receding upwards, are commonly discussed layout techniques that create (the illusion of) open space (e.g. Sorensen, 2009). Some layout techniques are employed to support the magnet effect. To stimulate interest, magnets require visibility, and therefore, Beddington (1982) suggests open sightlines. The 'chevroning' or 'fishbone' (Underhill, 2000), the grid (Fitch and Knobel, 1990), and the racetrack (Anic et al., 2010) layouts are amongst the most advocated in the literature. In museums, despite being more difficult to navigate and prone to creating chaotic circulation, free-form layouts are considered to reduce visitors' risk of boredom and satiation (Antón et al., 2018).

The third category, guiding techniques, includes soft and hard techniques. Soft techniques are characterised by being directive, rather than compulsory. The first soft technique is signage. Hanging signage with contrasting colours, visible from afar, is deemed most effective (Morgan, 2011). A second soft technique - difference in floor colour or surface in merchandise or exhibit areas - is a widely recognised influencer of movement (Fitch and Knobel, 1990; Levy and Weitz, 2009). Third, Zubiaga et al., (2019) suggest that smartphone applications with real-time information on visitor flows can guide tourists to less busy areas. While signage, floor designs and apps are generally directive, hard guiding techniques are compulsory. For example, in museums, Robillard (1982) suggests sending visitors on a fixed circulation route, from which they cannot deviate. Enseñat-Soberanis et al. (2019) found this technique to also be employed at cultural heritage sites. The fourth category of circulation management techniques relies on their appeal to consumers' curiosity and playfulness. Art trails (Pett, 2015) and gamification (Deterding et al., 2011) have been found to effectively influence circulation (Barnes, 2017). Contrary to the previously-identified technique involving open sightlines, some authors describe mystery as a force which can influence movement: Scott (1989) suggests blocking sightlines to create mystery. Similarly, Levy and Weitz (2009, p. 512), using the example of antiques stores, which, with their "nooks and crannies (...) entice shoppers to wander around", suggest creating mystery to entice the customer to explore the depth of the store by blocking the view with displays.

Although exhibition-management-level circulation techniques remain less thoroughly examined, particularly in academic research, some were identified. According to predominantly practitioner-written literature, exhibition managers use four types of techniques. Two of them, 
magnet (Schwartz, 2007; Hart, 2014; EventMB, 2017) and playfulness techniques (Schwartz, 2007; Champagne, 2015; Zhou, 2016; EventMB, 2017) were equally identified within the wider literature, while the use of exhibitor placement (Rinallo et al., 2010) and promotional techniques (EventMB, 2017) appears exclusive to exhibitions. Although the purposeful placement of products (magnets) is a common theme in the wider literature, the exhibitor placement techniques discussed in exhibition-specific literature differ in that all exhibitors are considered in relation to each other, rather than as individual units. Promotional techniques involve the use of marketing tools such as social media to draw attendees to the desired spots of the exhibition.

The literature review indicated that the majority of the body of research on circulation management stems from outside the exhibition context. As also demonstrated in the review, not only is research on circulation management in exhibitions limited, but there appear to be aspects of circulation management which are unique to exhibitions. Moreover, the exhibition context is different to that of other sectors where circulation management also takes a critical role in organisational success, such as retail and visitor attractions. As shown in Table 1, exhibitions hold a unique combination of characteristics across a number of dimensions relevant to circulation management, notably partial management control over circulation, temporary nature, the diverse set of products they entail and the high degree of concentration of visitors over a short period of time. Thus, investigating circulation management in the exhibition context may lead to findings that are not identifiable within others. Finally, and most importantly, despite being extensively researched in the wider literature, circulation management has not been investigated in terms of techniques, outputs and outcomes, irrespective of context. To develop a comprehensive understanding of the process as a whole, though, linking the three foci appears necessary, filling a gap both within exhibition and the wider literature.

\section{Table 1: Comparison of exhibitions context vis-à-vis other relevant contexts}

\begin{tabular}{|c|c|c|c|c|}
\hline Sector & $\begin{array}{l}\text { Level of } \\
\text { management } \\
\text { control }\end{array}$ & $\begin{array}{l}\text { Permanence in } \\
\text { location and } \\
\text { time }\end{array}$ & $\begin{array}{l}\text { Variety of products } \\
\text { within this context }\end{array}$ & $\begin{array}{l}\text { Number of people visiting } \\
\text { at once }\end{array}$ \\
\hline Exhibitions & $\begin{array}{l}\text { Partial: share } \\
\text { decision-making } \\
\text { power with } \\
\text { exhibitors }\end{array}$ & Temporary & $\begin{array}{l}\text { Diverse: e.g. B2B, } \\
\mathrm{B} 2 \mathrm{C} \text {, formal, informal }\end{array}$ & $\begin{array}{l}\text { Attendee numbers } \\
\text { concentrated over a short } \\
\text { period of time }\end{array}$ \\
\hline Theme parks & Complete & Permanent & Homogeneous & $\begin{array}{l}\text { Large visitor numbers } \\
\text { concentrated in high } \\
\text { season }\end{array}$ \\
\hline Museums & Complete & Permanent & $\begin{array}{l}\text { Diverse: participatory } \\
\text { museums, art } \\
\text { exhibitions, non- } \\
\text { purpose-built } \\
\text { museums (e.g. artist's } \\
\text { birth place) }\end{array}$ & $\begin{array}{l}\text { Visitor numbers generally } \\
\text { diluted }\end{array}$ \\
\hline $\begin{array}{l}\text { Retail (e.g. } \\
\text { supermarkets, } \\
\text { department stores, } \\
\text { clothing stores) }\end{array}$ & Complete & Permanent & Homogeneous & $\begin{array}{l}\text { Visitor numbers generally } \\
\text { diluted (excluding special } \\
\text { events, e.g. Black Friday) }\end{array}$ \\
\hline Shopping centres & $\begin{array}{l}\text { Partial control: } \\
\text { share decision- } \\
\text { making power with } \\
\text { tenants }\end{array}$ & Permanent & Homogeneous & $\begin{array}{l}\text { Visitor numbers generally } \\
\text { diluted (excluding special } \\
\text { events) }\end{array}$ \\
\hline
\end{tabular}




\section{Methodology}

Through prompting and probing, interviews with 10 England-based exhibition managers were carried out (Flick, 2009) between January and March 2019 in order to make explicit their tacit knowledge which is difficult to articulate (Stephens, 2010). As suggested by Muskat and Deery (2017), pragmatic knowledge and knowledge of best practice is often tacit in nature. Since event managers, whose knowledge is often based on common sense and experience (Smith, 2001) because the unpredictable nature of the industry requires bespoke solutions to everchanging problems (Muskat and Deery, 2017), rely heavily on both pragmatic and best-practice knowledge, it appears reasonable to assume that their knowledge is tacit and thus requires elicitation. Besides, it was expected that the links between techniques, outputs and outcomes would be tacit, and thus remain unelicited unless prompted.

The interviews consisted of two parts. The first part involved open-ended questions, while the second involved stimulus material. Questions were guided by the aim of the study. Therefore, they focused on extracting why and how exhibition managers manage circulation. It was important to exhaust the exhibition managers' explicit knowledge before using stimulating techniques to elicit semi-tacit knowledge (Fincher and Tenenberg, 2005) due to the risk of limiting the range of possible responses by providing stimulus material (Barton and McCully, 2005) early in the conversation. The first part involved two types of questions; a 'why' question aimed to elicit the outputs and outcomes of circulation management and a 'how' question extracted techniques employed by exhibition managers to influence circulation. Extensive probing was carried out to identify all freely-available knowledge of techniques, outputs and outcomes. The second part involved stimulus material, which was needed because tacit knowledge is contextual, and its elicitation, therefore, requires relevant contexts to be brought into focus (Mason, 2002). A card-sorting technique involving flash cards labelled with techniques discussed in the literature review was chosen, which acted as a springboard for discussion (Punch 2002) and prompted the exhibition managers' memory, making answers more accurate and allowing insight into aspects otherwise left undiscussed (Arksey and Knight, 1999). The exercise involved exhibition managers sorting the cards into two piles: The first signified that they used the technique to influence circulation in exhibitions, the second indicated the opposite. After this initial sorting, the exhibition managers were asked to discuss the techniques in the first pile and explain their purpose.

Using purposive sampling, the participants were selected based on their profession as exhibition managers in order to achieve the research aim (Fox et al., 2014). Exhibition managers with a minimum of one year's full-time experience were invited to participate, qualifying them as credible informants of exhibition management practices (Johnson and Weller, 2001). Another important selection criterion was that they managed entire exhibitions, not individual stands. The sample benefitted from the majority of participants being in senior roles, and from a variety of industry backgrounds, levels of professional experience and geographical areas and venues in which they operate. It represented varying sizes and types of exhibitions, from B2B trade shows to employment fairs, which differ considerably in terms of audience (Table 2). This diverse sample allows the presentation of different perspectives (Creswell, 2012) and is thus thought to capture circulation management in all its facets across the exhibition industry. The names of participants were changed to maintain anonymity.

Data analysis was conducted in NVIVO, following Braun and Clarke's (2006) six phases of thematic analysis. After familiarisation with the data which started with transcription, in alignment with the research objectives, the overarching themes were 'techniques', 'outputs', and 'outcomes'. The exploratory component was centred on the identification, initial categorisation and labelling of the specific techniques, outputs and outcomes. All instances 
were considered, which means that the theme was only required to be cited once to be considered relevant. The definitions of techniques, outputs and outcomes were used as a basis for identifying relevant meanings in the data set. An additional layer of exploration involved searching for other major themes that could contribute to increasing our understanding of circulation management. Early in the analysis it became evident that participants often referred to factors that influenced their decision to use a technique. Therefore, given the richness and the relevance of the data, this theme was added to the analysis and to the final model. Once preliminary themes were identified, themes were reviewed and all data re-examined to sort remaining codes into themes, resulting in the development of the final analytical framework.

Table 2: Participant characteristics

\begin{tabular}{|c|c|c|c|c|c|c|c|}
\hline Participant & Gender & $\begin{array}{l}\text { Length of } \\
\text { experience }\end{array}$ & Job title & $\begin{array}{c}\text { Type of } \\
\text { exhibitions }\end{array}$ & $\begin{array}{c}\text { Geographical } \\
\text { area of } \\
\text { operations }\end{array}$ & $\begin{array}{l}\text { Participant } \\
\text { recruitment } \\
\text { process }\end{array}$ & $\begin{array}{l}\text { Interview } \\
\text { length \& } \\
\text { setting }\end{array}$ \\
\hline \multicolumn{8}{|c|}{ Interview sample } \\
\hline Ellie & Female & 1 year & $\begin{array}{c}\text { Event } \\
\text { Assistant }\end{array}$ & Trade shows & $\begin{array}{l}\text { London, } \\
\text { England }\end{array}$ & $\begin{array}{c}\text { Personal } \\
\text { contact }\end{array}$ & $\begin{array}{l}47 \text { minutes; } \\
\text { office }\end{array}$ \\
\hline Richard & Male & 21 years & $\begin{array}{c}\text { Group } \\
\text { Exhibition } \\
\text { Manager }\end{array}$ & Trade shows & Worldwide & $\begin{array}{l}\text { LinkedIn } \\
\text { search }\end{array}$ & $\begin{array}{l}51 \text { minutes; } \\
\text { board room }\end{array}$ \\
\hline Charles & Male & 8 years & $\begin{array}{c}\text { Commercial } \\
\text { Director }\end{array}$ & Expos & $\begin{array}{c}\text { United } \\
\text { Kingdom }\end{array}$ & Snowball & $\begin{array}{l}42 \text { minutes, } \\
\text { board room }\end{array}$ \\
\hline Sharon & Female & 14 years & $\begin{array}{l}\text { Head of } \\
\text { Events }\end{array}$ & Congresses & Worldwide & $\begin{array}{c}\text { Personal } \\
\text { contact }\end{array}$ & $\begin{array}{c}11 \text { minutes; } \\
\text { café }\end{array}$ \\
\hline Antony & Male & 5 years & $\begin{array}{c}\text { Employment } \\
\text { Officer }\end{array}$ & $\begin{array}{c}\text { Employment } \\
\text { fairs } \\
\end{array}$ & $\begin{array}{l}\text { South of } \\
\text { England }\end{array}$ & Snowball & $\begin{array}{c}42 \text { minutes; } \\
\text { café }\end{array}$ \\
\hline Paul & Male & 22 years & Director & Trade shows & Far East & $\begin{array}{c}\text { LinkedIn } \\
\text { search }\end{array}$ & $\begin{array}{l}57 \text { minutes; } \\
\text { office }\end{array}$ \\
\hline Kirsty & Female & 6 years & $\begin{array}{c}\text { Head of } \\
\text { Conference }\end{array}$ & Expos & $\begin{array}{c}\text { United } \\
\text { Kingdom }\end{array}$ & $\begin{array}{c}\text { Personal } \\
\text { contact }\end{array}$ & \multirow{2}{*}{$\begin{array}{l}52 \text { minutes; } \\
\text { café }\end{array}$} \\
\hline Sophie & Female & 2 years & $\begin{array}{c}\text { Conference } \\
\text { Producer }\end{array}$ & Expos & $\begin{array}{c}\text { United } \\
\text { Kingdom }\end{array}$ & $\begin{array}{c}\text { Snowball, } \\
\text { introduced by } \\
\text { Kirsty } \\
\end{array}$ & \\
\hline Emily & Female & 20 years & $\begin{array}{l}\text { Operations } \\
\text { manager }\end{array}$ & Trade shows & $\begin{array}{c}\text { United } \\
\text { Kingdom }\end{array}$ & Snowball & $\begin{array}{l}25 \text { minutes; } \\
\text { board room }\end{array}$ \\
\hline Helen & Female & 3 years & $\begin{array}{c}\text { Exhibition } \\
\text { manager }\end{array}$ & Congresses & Worldwide & $\begin{array}{c}\text { Personal } \\
\text { contact }\end{array}$ & $\begin{array}{c}14 \text { minutes; } \\
\text { café }\end{array}$ \\
\hline \multicolumn{8}{|c|}{ Expert validation sample } \\
\hline Michelle & Female & 7 years & $\begin{array}{c}\text { Event } \\
\text { Manager }\end{array}$ & Trade shows & $\begin{array}{c}\text { United } \\
\text { Kingdom }\end{array}$ & $\begin{array}{c}\text { Personal } \\
\text { contact }\end{array}$ & $\mathrm{n} / \mathrm{a}$ \\
\hline Stephen & Male & $40+$ years & $\begin{array}{l}\text { Agency } \\
\text { owner }\end{array}$ & Congresses & Worldwide & $\begin{array}{c}\text { Personal } \\
\text { contact }\end{array}$ & $\mathrm{n} / \mathrm{a}$ \\
\hline Misoon & Female & 15 years & $\begin{array}{c}\text { Deputy } \\
\text { General } \\
\text { Venue } \\
\text { Manager }\end{array}$ & Various & Korea & $\begin{array}{l}\text { Personal } \\
\text { contact }\end{array}$ & $\mathrm{n} / \mathrm{a}$ \\
\hline Anastasia & Female & 5 years & $\begin{array}{c}\text { Senior } \\
\text { Conference } \\
\text { Producer }\end{array}$ & Conferences & Russia & $\begin{array}{l}\text { Personal } \\
\text { contact }\end{array}$ & $\mathrm{n} / \mathrm{a}$ \\
\hline
\end{tabular}


Two procedures were adopted to increase the trustworthiness of the study (Lincoln and Guba, 1985). First, peer review was carried out in two ways. After preliminary analysis by one of the authors, another (more experienced) researcher independently analysed the data. The two analyses were then compared, and any gaps discussed. While the structure of the overall model did not change, this exercise resulted in a small number of additions to two of the four major components of the model: a ninth technique and nine factors influencing the use of techniques were added. Arguably, factors can be subjective as often their influence is implied rather than explicitly stated, hence the ability of the more experienced researcher to identify additional factors. Peer review also involved asking four different exhibition managers based in the United Kingdom (2), Russia and South Korea to read through the report and comment on two elements (July/August 2019): how comprehensive the model was (if all circulation management techniques, outputs, outcomes and factors were captured) and how fair interpretations were. These steps contributed to ensuring the comprehensiveness and sound interpretation of the data (Elo et al., 2014). Second, rich and thick descriptions of participants' answers are provided to allow the reader to assess the fairness of the interpretation (Graneheim et al., 2017).

\section{Findings}

\subsection{Outcomes}

Outcomes are defined as the benefits to participants, exhibitors and the exhibition organiser caused by the improved circulation performance. Three kinds of outcomes were identified: organiser, exhibitor and attendee outcomes. An initial finding of the study was that

'within exhibitions, you are permanently schizophrenic because you have a number of masters that you are serving at the same time.' (Paul)

This indicates that managing different stakeholders' circulation outcomes is challenging for exhibition managers due to the need to balance often conflicting interests.

\subsubsection{Organiser outcomes}

Organiser outcomes are produced for the benefit of the exhibition-organising company. The outcomes were identified as health and safety, intermediate and end outcomes. The end outcome is the financial benefit for the organising company, i.e. maximum revenue and yield achieved from the exhibition. As Paul states,

\section{'do not romanticise exhibitions. They're about generating money, about selling square metres.'}

The intermediate outcomes are means to the financial end outcome. The first intermediate outcome, client retention, affects the financial outcome because it translates into the second, repeat ticket and stand sales. The third intermediate outcome involves increased stand prices: Circulation management resulting in adequate circulation to stands raises the amount organisers can charge for them, which resembles shopping centre pricing strategy (Shanmugam, 2013). Finally, it helps exhibition managers sell stands. As Richard explains,

'we're maximising the yield by making sure that every location in the show is attractive.' 
Space not being sellable is a concern for exhibition managers, potentially founded in the "troubling numbers for the trade show industry" (McMillin, 2017).

Despite affecting the entire audience's safety, health and safety outcomes were classified as organiser outcomes because they satisfy exhibition managers' aim to ensure safety, and fulfil their legal and moral obligations. At shows with large attendee numbers, circulation management is necessary to avoid bodily harm, while at exhibitions with lower attendance, crowding is not perceived a risk, and health and safety outcomes are viewed as a fulfilment of legal obligations. Finally, health and safety outcomes represent the fulfilment of exhibition managers' moral obligations. Paul, who specialises in exhibitions in the Far East, reports differences in the strictness of laws, but adds

'there is that moral obligation. Even if you can, doesn't mean you should do it.'

This shows that although exhibition managers may not be bound by laws in the country of operation, they want to fulfil their moral obligation.

\subsubsection{Client outcomes}

Client outcomes, i.e. attendee and exhibitor outcomes, are closely linked with organiser outcomes because their achievement evokes positive attitudes towards the exhibition. As Charles points out, adequate circulation management means that

'they have a good experience and are therefore more likely to re-book for next year.'

This shows that positive attitudes towards the exhibition can evoke the intention to return, which directly translates into the organiser outcome 'exhibitor and attendee retention'. Thus, exhibition managers aim to achieve client outcomes because they directly affect organiser outcomes.

Exhibition managers influence circulation to achieve a variety of exhibitor outcomes, which were classified as 'quantifiable' or 'affective'. The three quantifiable outcomes are the exhibitors' return on investment (ROI), the number of sales conversations held and the number of leads developed. Exhibitors judge the value of their participation by these outcomes. The quantifiable outcomes are also antecedents for the three affective exhibitor outcomes, which are personal success, feeling valued, and feeling happy. For example, high ROI can translate into personal success and professional recognition for the stand manager:

'Their bosses are happy because they've chosen the right expo so yeah, it's all about ROI.' (Kirsty)

The second affective exhibitor outcome, feeling valued, applies to small exhibitors. By helping them make the most of their show, exhibition managers ensure they feel equally as valued as the large companies. The third affective exhibitor outcome concerns happiness and is twofold: firstly, exhibition managers want exhibitors to be happy with their stand location in terms of footfall, and secondly, with the service supplied by exhibition management, for example reacting to and resolving circulation problems.

The five attendee outcomes of circulation management are positive experience, absence of negative emotions, feeling valued, networking and time maximisation. The first involves the experience being easy and smooth, and is closely related to the second which involves the absence of negative emotions such as frustration and confusion. The third outcome, feeling 
valued, encompasses attendees feeling equally as valued as exhibitors, which particularly applies to paying attendees:

'they were paying, at times, over a thousand pounds for a one-day pass, so we didn't just want to maliciously punt them out to exhibitors on their way in' (Charles).

The fourth attendee outcome is networking, which is a key motivation for attending trade shows (Kitchen, 2017). It is a result of the output 'buzz' and the close bodily proximity that comes therewith:

'It's good to be rubbing up against each other, because that's when the networking happens.' (Kirsty)

Finally, exhibition organisers

'have a responsibility to anyone who visits that they maximise their time, that they fulfil everything they want to fulfil.' (Antony)

Thus, time maximisation involves the avoidance of delays, which contributes to a smooth experience.

\subsection{Outputs}

Outputs refer to the tangible enhancements in the performance of the exhibition resulting from changes in circulation dynamics and in this research, six outputs were uncovered: greater footfall, better exposure to exhibits, increased dwell time, enhanced navigation, greater buzz, and managed congestion levels. Footfall and the exposure of attendees to exhibits required designing circulation to cover the entire exhibition, which is a key objective of circulation management:

'You're trying to encourage circulation of the visitor throughout the show, you want to make sure they go to all the corners of the show, not just one end.' (Paul)

To persuade attendees to visit every part of the exhibition, exhibition managers employ techniques making attendees aware of the different parts, and enticing them to explore. Creating this awareness and subsequent coverage is a major concern for organisers, as it decreases the risk of attendees missing out while increasing the saleability of remote spaces. This output prevents the existence of dead spaces, which subsequently increases the likelihood that all exhibitors receive satisfactory amounts of footfall and exposure, not just those able to afford prime locations with naturally high footfall:

'The principal thing you are trying to arrange is that all exhibitors are seeing a steady, regular flow of visitors to their stands.' (Paul)

The necessity to ensure that all stands receive satisfactory amounts of footfall is also reflected in the finding that a stand location which receives less footfall than others is one of the main reasons for exhibitors not to return-exhibit at future events (Qi et al., 2018). Additionally, attendees covering the entire exhibition increase their exposure to exhibitors and their products. Thus, exhibition managers resemble shopping centre management which aims "to maximise shoppers' exposure to the temptations of the centre and the blandishments of its occupants" (Brown, 1991, p. 17). 
The third output is dwell time, i.e. the amount of time attendees spend at the exhibition. It is closely connected to footfall, because the amount of footfall exhibitors receive increases with the amount of time attendees circulate through the space. The fourth output is navigation, also identified in secondary literature. Circulation management facilitates orientation and reduces confusion, ultimately contributing to a smooth and easy experience, without delays. As Charles explains,

'you want them to be able to get to that theatre they are trying to find very quickly and easily.'

However, exhibition managers do not seem to be concerned with satiation or boredom, two outputs of navigational difficulties discussed in museum research. Because generating value for visitors from interaction with exhibits is the responsibility of curators, they manage circulation to avoid this output (Antón et al., 2018). Exhibition managers' primary responsibility, on the other hand, is to provide the opportunity for interaction between exhibitor and attendee, irrespective of its quality, as Paul exemplifies,

\section{'you are bringing people into the hall, and they are bringing their product into the hall... If their sales people are confident enough, nature should take its own course.'}

This indicates that navigational difficulty resulting in satiation and subsequently less successful sales conversations is not a concern for exhibition managers. This finding is surprising considering that exhibitors and attendees evaluate the quality of exhibitions partly based on quality interaction opportunities (Tafesse, 2014). Besides exhibition managers not feeling responsible for quality interaction, attendees not being the main revenue stream, which differentiates exhibitions from museums, could be a plausible explanation for this finding.

The fifth output reflects the need to manage congestion levels. Different congestion levels have different purposes. On the one hand, high congestion levels, i.e. bottlenecks and extreme crowd densities, concern managers of exhibitions with particularly high attendance due to their health and safety implications. On the other hand, though, exhibition managers' main concern is with the lack of attendees in the exhibition, rather than crowding. In fact, exhibition managers appear to purposefully create congestion to create buzz, an output previously not identified by circulation literature, because circulation management is primarily employed to disperse crowds (Ahmadi, 1997). While extreme crowding is undesirable, in exhibitions, moderate crowding is intentional because it results in the atmospheric consequence of 'buzz':

'The ideal scenario for any exhibition organiser is that it's a really busy and buzzy expo and that it feels jam-packed.' (Kirsty)

Buzz evokes positive attitudes in exhibitors because busyness is perceived as conducive to doing business and as an antecedent of satisfactory ROI. Furthermore, moderate spatial limitation can positively affect attendees, because it contributes to networking. However, when buzz is the result of extreme crowd densities, which may be the case at particularly large shows, it can frustrate attendees and be dangerous. In summary, there is a fine line between buzz and overcrowding.

\subsection{Techniques}

In this study, techniques are manifest actions performed by exhibition managers to influence circulation, and therefore means by which exhibition managers achieve the above outputs and outcomes. Four types of techniques were identified: magnet, layout, curiosity and playfulness, and guiding techniques. 
As expected, circulation is influenced by the attraction power of magnets. Magnets are placed at the far ends of the hall or dotted around, to draw attendees across the space,

'so they will be exposed to different opportunities, as they walk around. Same as supermarkets putting the milk at the back of the shop.' (Antony)

They are attributed particular importance in areas with a low footfall expectancy in order to avoid dead areas, as Richard explains,

\section{you put your little honeypot in the corner and all the other companies will want to go around it'}

therefore making space in remote locations more sellable.

Magnets were classified into 9 categories, as shown in Figure 1. Some magnets generate conflicting outputs. For example, seating counteracts the intent to create congestion for buzzpurposes. Similarly, queuing equally generates conflicting outputs and outcomes: on the one hand, queues can be time-consuming and a nuisance for attendees, and are consequently avoided by exhibition managers. On the other hand, as Sharon said 'there was a long queue [for a popular feature] and that's what we wanted' because it indicates their desirability. Queues draw attendees' attention and attract them to the feature or exhibitor.

\section{Figure 1: Techniques employed to manage circulation}

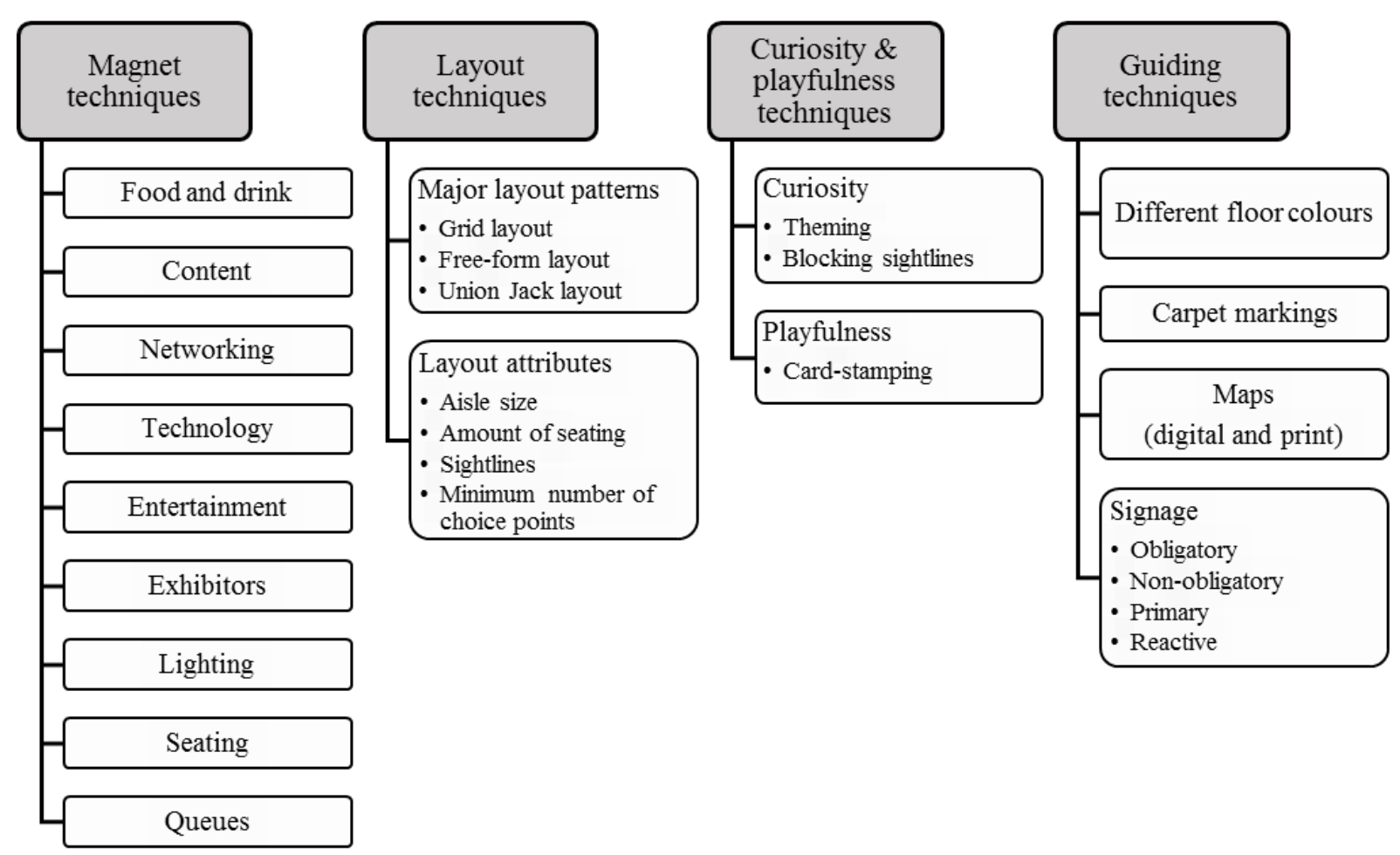

The second of the four circulation management techniques comprises layout techniques, which can be split into two types, major layout patterns and layout attributes. Major layout patterns include the grid layout, the free-form layout and the Union Jack layout which was previously not identified within the wider literature. Layout attributes, of which 4 were identified (size of the aisles, seating, open/blocked sightlines and intersection choice), describe the specific layout decisions made irrespective of the chosen major layout. 
Some participants view wide aisles as a prerequisite for networking and sales conversations: attendees feel they can step to one side and stop to interact with exhibitors without hindering other attendees from circulating. This shows that in exhibitions, wide aisles have a different purpose than in other contexts, where they are used as magnets based on the finding that open space attracts (Sorensen, 2009). On the other hand, because many exhibition managers aim to generate actual crowds or the perception thereof, to create perceived busyness, they decrease aisle widths:

\section{'It's probably not any busier at that particular time, but if you compact everything, it feels busier.' (Charles)}

The third category of circulation management techniques constitutes those appealing to attendees' playfulness by gamifying their experience. One technique involves card-stamping exercises, incentivising attendees to cover the entire exhibition by the prospect of being entered into a prize draw. Other techniques influence circulation by appealing to attendees' curiosity, for example:

'We have different themes in each room, and I think that mystery of not knowing what the theme looks like in each room... People are intrigued.' (Ellie)

Theming entices attendees to explore the exhibition, an effect which is also achieved by blocking sightlines.

Four guiding techniques were revealed, which primarily achieve attendee outcomes: different floor colours, markings on the carpets, maps and signage. Signage was considered an essential guiding technique by all participants. Signage includes obligatory signage (which signposts emergency exits and regulates circulation during emergencies), and non-obligatory signage. Exhibition managers describe signage as being most effective when it is suspended from great heights and is clearly legible due to the use of strongly contrasting colours, thus confirming Levy and Weitz's (2009) suggestion. In Ellie's opinion, however,

'signage on a board is very easily missed by visitors so we make sure that we have human signage available.'

The use of human resources in signposting, uncommon in other industries probably due to cost, may be a result of the amount of volunteers typically involved in events (Weidenfeld and Leask, 2013). Besides primary signage, which is installed prior to the exhibition-opening, there is reactive signage, which addresses specific circulation problems not foreseeable pre-event, identified through circulation-monitoring.

\subsection{Factors influencing the employment of techniques}

The exploration of techniques revealed that their employment is not universal and depends on 20 factors which are presented and illustrated with examples in Table 4. The collection of factors influencing the employment of circulation management techniques provides an understanding of the complexities of circulation management at exhibitions. It could be of particular interest to exhibition practitioners, as it provides guidance regarding which factors to consider during the planning of circulation management. The findings illustrate that exhibitions are diverse, and generic solutions do not apply. Thus, circulation management needs to be approached with the unique features of the individual exhibition and its audience in mind. 
Table 3: Techniques employed to manage circulation

Techniques

\begin{tabular}{|c|c|c|}
\hline \multicolumn{3}{|c|}{ Magnet techniques } \\
\hline \multirow[t]{9}{*}{ Types of magnets } & Food and drink & $\begin{array}{l}\text { Food stalls and drinks, particularly tea and coffee, attract } \\
\text { attendees. }\end{array}$ \\
\hline & Content & $\begin{array}{l}\text { Content, such as workshops and lectures, act as both } \\
\text { space (physically attract attendees) and time (motivate } \\
\text { attendees to arrive earlier or leave later) magnets. }\end{array}$ \\
\hline & Networking & $\begin{array}{l}\text { Networking lounges are attractive to delegates who seek } \\
\text { to develop contacts. }\end{array}$ \\
\hline & Technology & $\begin{array}{l}\text { Phone-charging stations or Wi-Fi hotspots attract } \\
\text { attendees who want to catch up on work. }\end{array}$ \\
\hline & Entertainment & $\begin{array}{l}\text { Entertainment magnets such as performances or product } \\
\text { showcases attract attendees. }\end{array}$ \\
\hline & Exhibitors & $\begin{array}{l}\text { Exhibitors who have a natural draw (e.g. company size, } \\
\text { brand popularity), use attention-grabbing interactive } \\
\text { stands/freebies or address needs of specific attendee } \\
\text { segments, act as magnets. }\end{array}$ \\
\hline & Lighting & $\begin{array}{l}\text { Lighting can attract attendees' attention, especially in } \\
\text { under-illuminated venues. }\end{array}$ \\
\hline & Seating & $\begin{array}{l}\text { When exhibitions are long and tiresome, attendees seek } \\
\text { opportunities to sit and take a break. }\end{array}$ \\
\hline & Queues & $\begin{array}{l}\text { Queues can attract attendees to a feature or exhibitor by } \\
\text { triggering fear of missing out (FoMO). }\end{array}$ \\
\hline \multirow{3}{*}{ Placement of magnets } & At the back & \multirow{3}{*}{$\begin{array}{l}\text { Magnets are placed strategically to pull attendees across } \\
\text { the space, particularly to areas with low footfall } \\
\text { expectancy. Magnets make remote areas of the } \\
\text { exhibition more sellable because they promise high } \\
\text { footfall. }\end{array}$} \\
\hline & At far ends & \\
\hline & Dotted around & \\
\hline \multirow[t]{3}{*}{ Major layout patterns } & Grid layout & $\begin{array}{l}\text { The grid layout involves standardised exhibition stands } \\
\text { being arranged in straight lines, i.e. in the shape of a } \\
\text { grid. }\end{array}$ \\
\hline & Free-form layout & The free-form layout is non-standardised. \\
\hline & Union Jack layout & $\begin{array}{l}\text { Involves placing magnets, such as content features, in the } \\
\text { four corners of the exhibition and building large diagonal } \\
\text { aisles to lead attendees to them from the centre of the } \\
\text { exhibition. }\end{array}$ \\
\hline \multirow[t]{4}{*}{ Layout attributes } & $\begin{array}{l}\text { Aisle size (narrow or } \\
\text { wide) }\end{array}$ & $\begin{array}{l}\text { Wide aisles can be used to increase interaction and } \\
\text { address health and safety risks at shows with high } \\
\text { attendance, while narrow aisles are used to generate } \\
\text { crowds or the perception thereof, to create buzz. }\end{array}$ \\
\hline & Seating & $\begin{array}{l}\text { Although seating is an essential consideration in the } \\
\text { creation of floorplans, exhibition managers may refrain } \\
\text { from providing them to keep attendees on their feet and } \\
\text { moving to increase buzz. }\end{array}$ \\
\hline & $\begin{array}{l}\text { Sightlines (open or } \\
\text { blocked) }\end{array}$ & $\begin{array}{l}\text { Open sightlines facilitate navigation due to providing } \\
\text { orientation and increasing the visibility of higher stands } \\
\text { at the back. While blocked sightlines can create a } \\
\text { mystery effect, they can also lead to unfair advantages } \\
\text { for those located in plain sight. }\end{array}$ \\
\hline & $\begin{array}{l}\text { Reduce choice at } \\
\text { intersections }\end{array}$ & $\begin{array}{l}\text { The number of directions attendees can choose to go at } \\
\text { an aisle intersection is kept to a minimum in order to } \\
\text { minimise confusion. }\end{array}$ \\
\hline
\end{tabular}


Table 3: Techniques employed to manage circulation (continued)

\begin{tabular}{|c|c|c|}
\hline \multicolumn{2}{|c|}{ Techniques } & Explanation \\
\hline \multicolumn{3}{|c|}{ Curiosity and Playfulness techniques } \\
\hline Curiosity & Theming & $\begin{array}{l}\text { Theming entices attendees to explore the exhibition by } \\
\text { appealing to their curiosity and their desire to discover } \\
\text { how the theming was implemented in different parts of } \\
\text { the exhibition. }\end{array}$ \\
\hline Playfulness & Card-stamping exercise & $\begin{array}{l}\text { Card-stamping exercises incentivise attendees to cover } \\
\text { the entire exhibition by the prospect of being entered into } \\
\text { a prize draw. }\end{array}$ \\
\hline \multicolumn{3}{|c|}{ Guiding techniques } \\
\hline \multirow[t]{2}{*}{ Floor techniques } & Floor colours & $\begin{array}{l}\text { Different areas of the exhibition are demarcated with } \\
\text { different floor colours. }\end{array}$ \\
\hline & Markings on carpet & $\begin{array}{l}\text { Markings on the carpets are used to give directions to } \\
\text { attendees, allowing them to follow a particular symbol or } \\
\text { colour to their destination. }\end{array}$ \\
\hline Maps & & Exhibition maps are provided (digitally or in print). \\
\hline \multirow[t]{4}{*}{ Signage } & Obligatory signage & $\begin{array}{l}\text { Obligatory signage signposts emergency exits and } \\
\text { regulates circulation during emergencies. }\end{array}$ \\
\hline & Non-obligatory signage & $\begin{array}{l}\text { Non-obligatory signage is all other signage enhancing } \\
\text { navigation and can be, for example, human signage, } \\
\text { hanging signage or board signage. }\end{array}$ \\
\hline & Primary signage & $\begin{array}{l}\text { Primary signage includes the signage installed prior to } \\
\text { the exhibition opening. }\end{array}$ \\
\hline & Reactive signage & $\begin{array}{l}\text { Reactive signage addresses specific circulation problems } \\
\text { not foreseeable pre-event, identified through circulation- } \\
\text { monitoring. }\end{array}$ \\
\hline
\end{tabular}

\subsection{Expert validation}

The four exhibition experts who participated in the validation exercise all deemed the research to be interesting and representative of circulation management at exhibitions. Anastasia's comment reflects the consensus among experts:

'The findings presented in this paper match my experience; everything seems logical to me'.

Overall, the model was described as 'thoroughly comprehensive' (Michelle), 'represents the circulation management process well' (Misoon), and even educational to some exhibition managers, who 'could learn a lot from the read' (Michelle). The representation of circulation management as a complex process during which 'the opposing forces present' (Stephen) must be managed by exhibition managers was praised.

The factors influencing the employment of techniques, particularly the ones considering different types and sizes of exhibitions, were found accurate and according to several experts, allowed a thorough understanding of circulation management. However, some experts explained they would like the findings to better reflect how exactly the size, industry context, audience or budget of the exhibition influenced the employment of circulation management techniques. Stephen pointed out that the motivation for the exhibitors can differ from day to day, audience to audience', and that he felt that although the findings touch upon such differences, they should be more explicit. While the development of such an understanding 
would add to the knowledge about circulation management, it is outside the scope of this exploratory research to detail how each influencing factor shapes the employment of techniques. Future research could be developed to examine the interplay between influencing factors and the deployment of techniques.

\section{Table 4: Factors influencing the employment of circulation management techniques at exhibitions}

\begin{tabular}{|c|c|}
\hline Factor & Example \\
\hline \multicolumn{2}{|r|}{ Client-related factors } \\
\hline $\begin{array}{l}\text { Paying vs. non-paying } \\
\text { attendees }\end{array}$ & $\begin{array}{l}\text { Exhibition managers may refrain from placing magnets in distant locations, to } \\
\text { avoid paying attendees having to walk long distances. }\end{array}$ \\
\hline Industry characteristics & $\begin{array}{l}\text { Level of formality (formal/informal) and focus (networking, education) of an } \\
\text { industry influence the techniques employed. Industries characterised by } \\
\text { informality (e.g. creative industry) employ unconventional techniques such as } \\
\text { scavenger hunts. Certain industries' events emphasise networking at the } \\
\text { expense of educational content and techniques such as beer taps made available } \\
\text { on every stand, something that would be not considered in a medical sector } \\
\text { exhibition. }\end{array}$ \\
\hline Demand for the exhibition & $\begin{array}{l}\text { Revenue-reducing techniques such as seating as a magnet or wide aisles are } \\
\text { only employed if space remains unsold. }\end{array}$ \\
\hline Exhibitor requirements & $\begin{array}{l}\text { The placement of magnet exhibitors may be out of exhibition managers' control } \\
\text { due to exhibitors' logistical requirements and their striving for competitive } \\
\text { advantage. }\end{array}$ \\
\hline Stand attributes & $\begin{array}{l}\text { The employment of techniques depends on the standardisation and size of } \\
\text { exhibition stands. For example, the grid layout may not be applicable if the } \\
\text { exhibits are not standardised, which is particularly the case with interactive } \\
\text { stands which are seldom square booths. The employment of hanging signage } \\
\text { and wide aisles depends on the height of the exhibition stands. Hanging signage } \\
\text { remains visible in spite of high stands, and wide aisles increase their visibility } \\
\text { from surrounding areas. }\end{array}$ \\
\hline Cultural influence & $\begin{array}{l}\text { Exhibitions situated in Europe tend to be more organised and structured in their } \\
\text { layout, whereas those in Asia employ more free-form layouts. }\end{array}$ \\
\hline \multicolumn{2}{|r|}{ Exhibition-related factors } \\
\hline Number of concurrent shows & $\begin{array}{l}\text { The use of different floor colours to demarcate areas is more prominent in co- } \\
\text { located exhibitions, i.e. those which comprise more than one exhibition. }\end{array}$ \\
\hline Size of attendance & $\begin{array}{l}\text { Large attendee numbers mean that techniques for health and safety, e.g. wide } \\
\text { aisles, take priority over other techniques, e.g. narrow aisles to create higher } \\
\text { congestion levels and buzz. }\end{array}$ \\
\hline Size of exhibition & $\begin{array}{l}\text { Whilst smaller shows tend to spread out similar exhibitors to draw attendees } \\
\text { who are interested in the category across the hall, large exhibitions employ } \\
\text { 'zoning', i.e. group similar exhibitors together to give attendees a chance to } \\
\text { visit all in the time given. }\end{array}$ \\
\hline $\begin{array}{l}\text { Content- vs. booth-led } \\
\text { exhibitions }\end{array}$ & $\begin{array}{l}\text { The employment of techniques depends on whether the exhibition is primarily } \\
\text { content- or booth-focussed. For example, at content-led exhibitions, the main } \\
\text { magnets tend to be lecture theatres. }\end{array}$ \\
\hline $\begin{array}{l}\text { Insufficient circulation } \\
\text { performance }\end{array}$ & $\begin{array}{l}\text { Reactive signage in particular is employed to demonstrate proactivity in } \\
\text { representing exhibitor interests. Whilst they may be ineffective in driving traffic } \\
\text { to exhibitors, the stand managers feel valued and happy because the exhibition } \\
\text { manager appears to be working towards resolving circulation issues. }\end{array}$ \\
\hline
\end{tabular}


Table 4: Factors influencing the employment of circulation management techniques at exhibitions (continued)

\begin{tabular}{|c|c|}
\hline Factor & Example \\
\hline \multicolumn{2}{|r|}{ Organisational/Planning factors } \\
\hline $\begin{array}{l}\text { Degree of control over } \\
\text { location }\end{array}$ & $\begin{array}{l}\text { Whilst exhibition sales people can recommend stand locations, the control } \\
\text { ultimately lies with exhibitors who decide which stand location to buy. }\end{array}$ \\
\hline $\begin{array}{l}\text { Ability to communicate with } \\
\text { attendees pre-event }\end{array}$ & $\begin{array}{l}\text { Ticketed shows generally allow the exhibition manager to communicate with } \\
\text { the attendees, e.g. via e-mail. Pre-event communication is used to instil a sense } \\
\text { of mystery and evoke curiosity, or advise attendees to rely on electronic } \\
\text { schedules or floor plans, in case of any changes since the print deadline which } \\
\text { resulted in print brochures not being up-to-date. }\end{array}$ \\
\hline Cost & $\begin{array}{l}\text { Signage is a cost-factor, thus may be neglected in a trade-off with retaining } \\
\text { profit margins. }\end{array}$ \\
\hline Programme change & $\begin{array}{l}\text { The use of specific guiding techniques such as electronic signage is influenced } \\
\text { by potential programme changes, which require flexibility in signage and } \\
\text { schedule announcements. }\end{array}$ \\
\hline Health and safety regulations & $\begin{array}{l}\text { Although exhibition managers want to reduce aisle width to achieve maximum } \\
\text { buzz, in most countries, they are restricted in doing so by health and safety } \\
\text { regulations, which require a minimum width. }\end{array}$ \\
\hline Sustainability policy & $\begin{array}{l}\text { Exhibitions by organisations or in venues with sustainability policies have to } \\
\text { refrain from using techniques involving non-reusable items, such as floor } \\
\text { stickers. }\end{array}$ \\
\hline Venue design & $\begin{array}{l}\text { The exhibition layout may be dictated by the location of services, e.g. electrical } \\
\text { cabling, with which the stands need to align. }\end{array}$ \\
\hline \multicolumn{2}{|r|}{ Organiser-related factors } \\
\hline $\begin{array}{l}\text { Degree of accumulated } \\
\text { knowledge }\end{array}$ & $\begin{array}{l}\text { The employment of techniques depends on the exhibition manager's } \\
\text { accumulated knowledge, including venue knowledge and knowledge of } \\
\text { previous exhibitions and the current one. Venue knowledge and knowledge } \\
\text { resulting from data collected at previous exhibitions allows the exhibition } \\
\text { manager to intuitively make predictions of attendee circulation, whilst } \\
\text { observation and resulting knowledge of the current exhibitions allows them to } \\
\text { react to potential gaps in performance. }\end{array}$ \\
\hline Personal preference & $\begin{array}{l}\text { The grid layout, despite its popularity amongst some managers, is not employed } \\
\text { by others who find it uncreative and boring. }\end{array}$ \\
\hline
\end{tabular}

Furthermore, one exhibition expert recommended establishing which factors take priority over others in the context of different exhibition types, e.g. trade exhibitions or culture shows. Another expert suggested dividing the factors influencing the employment of techniques according to whether they can be affected by exhibition managers, or whether they are fixed, the latter of which was illustrated by the example of health and safety regulations which are irrefutable. Again, such detail is outside the scope of this research and could be covered in future research.

One minor recommendation that was adopted involved renaming one of the client-related factors. According to Michelle:

\section{'circulation techniques vary across different industries (...) For example, oil \& gas events love to network, you will find beer taps on every stand and very little educational content. Whereas the event I run in the medical sector values education first and foremost and attendees wouldn't drink the alcohol if it was offered to them"}

Therefore, the factor initially labelled 'level of formality' was renamed 'industry characteristics' to better reflect the two key industry characteristics identified in the study: level of formality and industry focus (education, networking). 


\section{Conclusions}

The study responds to the recent call by Tafesse and Skallerud (2017) to carry out organisercentred exhibition research. By being the first to uncover the techniques, outputs and outcomes of circulation management in the context of exhibitions, this paper reveals how circulation is managed in exhibitions while at the same time contributing to the wider literature on the topic. The outputs and outcomes of circulation management examine the reasons why exhibition managers manage circulation, while the circulation management techniques focus on what exhibition managers actually do to achieve these. The results are summarised in Figure 2, which presents the 'integrative circulation management model for exhibitions'.

Figure 2: Integrative model of circulation management at exhibitions

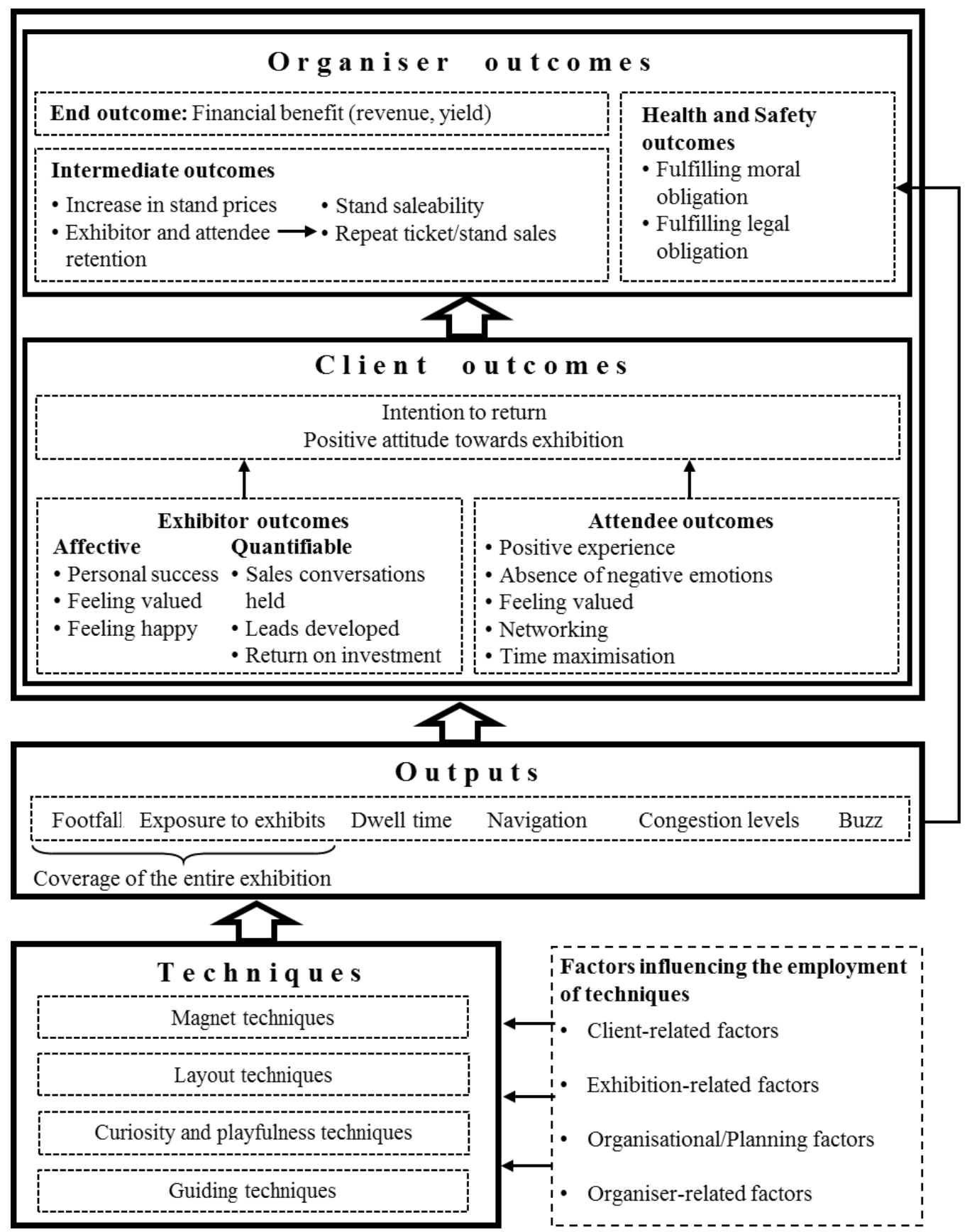


The study resulted from the suspicion that an exploration of circulation management within the unique context of exhibitions would add different dimensions to existing knowledge, based on differences identified in Table 1. Interviews with England-based exhibition managers confirmed that there are elements which are unique to circulation management of exhibitions. The outcomes were classified into organiser, exhibitor and attendee outcomes, adding to existing knowledge in two ways. Firstly, the findings established the organiser dimension as the end outcome of circulation management. They clearly position client outcomes as a prerequisite for organiser outcomes, thus underpinning practitioner literature (e.g. Zhou, 2016). Health and safety outcomes, also classified as organiser outcomes, were not previously connected to circulation management. Secondly, the findings indicate that exhibition managers have an interest in achieving attendee outcomes, similar to visitor attraction research, thus adding a new perspective to otherwise predominantly exhibitor-focussed exhibition literature (e.g. Champagne, 2015). However, the study also found that while attendee outcomes are considered important, exhibitor and organiser outcomes are often prioritised. This is founded in the predominance of the financial organiser outcome, which takes priority over other outcomes.

Six outputs of circulation management were identified: footfall and exposure to exhibits (which requires covering the entire exhibition), dwell time, navigation, congestion levels and buzz. While dwell time and buzz are new findings, maximum coverage of the exhibition and footfall were expected outputs following the literature review (Hart, 2014; EventMB, 2017). Because existing literature is predominantly exhibitor-focussed, the finding that exhibitions match museums in the importance placed upon exposing visitors to worthwhile exhibits (Klein, 1993) was new. However, although navigation was identified as an output of circulation management, unlike museum curators, exhibition managers are not concerned about satiation or boredom (Antón et al., 2018). Dwell time concerns the amount of time attendees spend at the exhibition, and is linked to footfall for exhibitors which is increased through extended dwell time. The results show that avoiding congestion is not a universal concern for exhibition managers, as it is for theme park managers, who seek to disperse crowds (Ahmadi, 1997; Zhang et al., 2017). Furthermore, both buzz and the creation of congestion demonstrate that exhibitor outcomes take priority over attendee outcomes, because, while they satisfy exhibitors, they can dissatisfy attendees by resulting in spatial limitation.

Circulation management techniques employed by exhibition managers included magnet, layout, playfulness, and guiding techniques. They differ significantly from the techniques identified within practitioner research, but resemble those identified in wider research. However, reactive guiding techniques were not previously identified because they are much less significant in contexts which are more permanent in spatio-temporality. Due to being temporary and focussed within a short time period, exhibition management must react to circulation issues quickly and spontaneously, unlike visitor attractions and retail management who do not operate under such time constraints.

The exploration of techniques also resulted in the discovery of 20 factors influencing their employment (Table 4), a finding not covered in previous literature. The employment of circulation management techniques is related to four types of factors, namely: Client, exhibition, Organisational/Planning and Organiser factors. The existing literature had not identified that certain techniques would or would not be applicable under certain circumstances. As identified in Table 1, the exhibition context is much more diverse in terms of the products it includes, and based on the differences between individual exhibitions, circulation cannot be managed with one-size-fits-all techniques.

The model in Figure 2 represents a contribution to knowledge in both exhibition and wider literature, as circulation management has not previously been examined in terms of the 
relationship between techniques, outputs and outcomes. The integrated examination of techniques, outputs and outcomes revealed the conflict in some techniques and outputs, requiring exhibition managers to make trade-offs to achieve one at the expense of another, e.g. generating crowds to achieve buzz for exhibitors despite spatial limitation resulting in discomfort for attendees. This finding emphasises the complexity of circulation management at exhibitions. The visual representation clearly illustrates the hierarchy in outcomes, with all outcomes ultimately benefitting the organiser. The model's utility for exhibition managers is twofold: Reading it from bottom to top indicates the cascading effects of techniques on outputs and outcomes, and when reading it from top to bottom, it becomes a planning tool illustrating the steps needed for successful circulation management.

The results of this study are of benefit to exhibition managers, educators, exhibitors and circulation managers in other sectors. An understanding of the best practice in circulation management allows exhibition managers to reflect on their own practice with a view to expanding the variety of techniques they can employ, some of which they may be unaware of. At the same time, an understanding of the outputs and outcomes demonstrates the effects of deploying those techniques on attendee circulation, allowing them to make the case for adopting particular techniques. Similarly, the multiple benefits of managing circulation for the exhibitor, attendee and organiser are revealed, thus making a compelling case for circulation management as a key activity within exhibition management. The paper's usefulness for exhibition managers is further strengthened by the identification of a comprehensive range of factors influencing the employment of techniques, thus helping exhibition managers to make informed decisions about when to deploy which techniques.

The circulation management model for exhibitions adds to the body of knowledge available to those who are involved in exhibition management education. As seen in the literature review, knowledge on the topic is scant and is often scattered across (predominantly) industry contributions. The comprehensive model developed here can encourage educators to embed circulation management in their syllabus, while at the same time allowing those who already cover it to address the topic more holistically.

Exhibitors may benefit from the study's findings in two ways: firstly, by becoming knowledgeable in the techniques available to exhibition organisers, exhibitors are enabled to recommend or even demand their use to maximise the outcomes beneficial to them and their exhibition performance. For example, exhibitors placed in locations that they deem less suitable to expected numbers of attendees, can negotiate the implementation of some of the techniques identified in the study with a view to improving the likelihood that the booth will receive the necessary flow of participants. Secondly, the study provides exhibitors with criteria by which they are able to evaluate the exhibition and its organisers' performance. Specifically, being aware of the techniques available to the exhibition organiser, exhibitors can evaluate whether adequate measures were taken to ensure high levels of footfall and the exhibitor's success at the exhibition.

The study also provides useful findings for the fourth category of beneficiaries, containing managers of circulation in other contexts. While exhibitions differ from other research contexts as described in Table 1, due to recent trends towards pop-up experiences in traditional industries such as retail (Warnaby and Shy, 2019), museums (Nguyen, 2020) and food service (Niroo and Van Winkle, 2019), the delineations between those contexts and events are becoming increasingly blurred. For example, pop-up experiences resemble exhibitions by dint of not being permanent in space and time, and their use and transformation of blank canvas spaces. As a result, other contexts are providing increasingly event-like experiences with 
characteristics similar to those of exhibitions; hence the findings applicable to exhibitions are potentially relevant to those contexts.

\subsection{Future research}

Although specific links between techniques, outputs and outcomes were made, they were not exhausted. Therefore, future research could make explicit the specific links between the three elements, using methods such as means-end theory. While this study focused on circulation management within the exhibition space, it should be noted that in the view of some exhibition organisers, the process of circulation management starts outside, prior to attendees entering the space. This includes their travel to the exhibition as well as the registration process. For example, the registration process may be sped up by encouraging attendees to pre-print their badges to avoid creating congestion and delays outside the entrances. As this study only considered the circulation management process within the premises, future research could investigate pre-arrival processes.

The study showed that the employment of techniques depends upon 20 factors, and therefore, further investigation could involve quantitative research into how these factors influence the use of technique and preference for outputs and outcomes. Researching specific segments of exhibitions, such as size and audience, may uncover patterns of interest to better circulation management practice. Deeper understanding could also be gained from evaluating the effectiveness of the techniques identified in this study. Quantitative studies examining the effects of techniques on attendee circulation will allow researchers to make statistically significant recommendations for future exhibitions, grounded in actual attendee circulation behaviour. Such investigation would also allow judgment on which techniques are more fruitful, and in what context, which would be particularly useful given that there are techniques which stand in direct conflict with each other, e.g. blocking versus keeping open sightlines. 


\section{References}

Adams, R., Coyle, T., Downey, C. and Lovett, M. (2017), "Macroeconomic impact on trade show goals", Journal of Business \& Industrial Marketing, Vol. 32 No. 5, pp. 710-721.

Ahmadi, R. H. (1997), "Managing Capacity and Flow at Theme Parks", Operations Research, Vol. 45 No. 1, pp. 1-13.

Angel, G. (2019), "Issues with shopper tracking and data quality: From solving multi-floor issues to driving better positional accuracy”, Applied Marketing Analytics, Vol. 5 No. 1, pp. 15-37.

Anic, I.-D., Radas, S. and Lim, L. K. S. (2010), "Relative effects of store traffic and customer traffic flow on shopper spending”, The International Review of Retail, Distribution and Consumer Research, Vol. 20 No. 2, pp. 237-250.

Anthony, E. (1963), “Approach, method and technique”, English Language Teaching, Vol. 17, pp. 63-67.

Antón, C., Camarero, C. and Garrido, M.-J. (2018), “A journey through the museum: Visit factors that prevent or further visitor satiation”, Annals of Tourism Research, Vol. 73, pp. 48-61.

Arksey, H. and Knight, P. T. (1999), Interviewing for social scientists: An introductory resource with examples, SAGE, London.

Barnes, M. (2017),” Family Trails For Town Centres”, available at: https://reviveandthrive.co.uk/family-trailsfor-town-centres/ (accessed 28 November 2018).

Barton, K. C. and McCully, A. W. (2005), "History, identity, and the school curriculum in Northern Ireland: An empirical study of secondary students' ideas and perspectives”, Journal of Curriculum Studies, Vol. 37 No. 1 , pp. 85-116.

Bauer, T. and Borodako, K. (2019), "Trade show innovations - Organizers implementation of the new service development process", Journal of Hospitality and Tourism Management, Vol. 41, pp.1 97-207.

Beddington, N. (1982), Design for Shopping Centres, Butterworth Scientific, London.

Bitgood, S. (1988), "Problems in Visitor Orientation and Circulation", Visitor Studies, Vol. 1 No. 1, pp. 155170.

Bitgood, S. (2006), “An Analysis of Visitor Circulation: Movement Patterns and the General Value Principle”, Curator, Vol. 49 No. 4, pp. 463-475.

Bitgood, S. (2009), “Museum Fatigue: A Critical Review”, Visitor Studies, Vol. 12 No. 2, pp. 93-111.

Bloch, P. H., Gopalakrishna, S., Crecelius, A. T. and Scatolin Murarolli, S. (2017), "Exploring booth design as a determinant of trade show success”, Journal of Business-to-Business Marketing, Vol. 24 No. 4, pp. 237256.

Braun, V. and Clarke, V. (2006), "Using Thematic Analysis in Psychology", Qualitative Research in Psychology, Vol. 3 No. 2, pp. 77-101.

Brown, S. (1991), "Shopper Circulation in a Planned Shopping Centre”, International Journal of Retail \& Distribution Management, Vol. 19 No. 1, pp. 17-24.

BVEP (2017), “Opportunities for Global Growth in Britain's Events Sector”, available at: https://www.google.de/url?sa=t\&rct=j\&q=\&esrc=s\&source=web\&cd=2\&ved=2ahUKEwjooeOhyznAhVUTsAKHQx-

AaIQFjABegQIARAB\&url=https $\% 3 \mathrm{~A} \% 2 \mathrm{~F} \% 2 \mathrm{Fwww}$.businessvisitsandeventspartnership.com\%2Fresearch -and-publications \%2Fresearch\%2Fcategory\%2F4-bvep-research\%3Fdownload\%3D285\%3Aopportunitiesfor-global-growth-in-britain-s-events-sector\&usg=AOvVaw0cYbpTxcA2Zs_38ij7Axhh (accessed 4 February 2019).

Champagne, C. R. (2015), "Help Your Exhibitors Drive Traffic to Their Booth", available at: https://strauss.ca/help-your-exhibitors-drive-traffic-to-their-booth/ (accessed 11 November 2018).

Chongwatpol, J. (2015), "Integration of RFID and business analytics for trade show exhibitors", European Journal of Operational Research, Vol. 244, pp. 552-673.

Chung, N., Koo, C. and Kim, J.K. (2014), "Extrinsic and intrinsic motivation for using a booth recommender system service on exhibition attendees' unplanned visit behaviour", Computers in Human Behavior, Vol. 30, pp. 59-68.

Creswell, J. W. (2012), Educational Research - Planning, conducting and evaluating quantitative and qualitative research, $4^{\text {th }}$ edition, Pearson, Boston, MA.

De Kruijf, J. A. M. and de Vries, M. S. (2018), "Contextualizing the trend from output to outcome measurement: the Dutch pension system”, Public Money \& Management, Vol. 38 No 1, pp. 65-72. 
Dejbakshs, S., Arrowsmith C. and Jackson, M. (2011), “Cultural Influence on Spatial Behaviour”, Tourism Geographies, Vol. 13 No. 1, pp. 91-111.

Deterding, S., Dixon, D., Khaled, R., and Nacke, L. (2011), "From Game Design Elements to Gamefulness: Defining "Gamification", in The $15^{\text {th }}$ International Academic MindTrek Conference: Envisioning Future Media Environments in Tampere, Finland, 28-30 September 2011, ACM, New York, pp. 9-15.

Elo, S., Kääriäinen, M., Kanste, O., Pölkki, T., Utriainen, K. and Kyngäs, H. (2014), “Qualitative content analysis: A focus on trustworthiness", SAGE open, Vol. 4 No. 1, pp. 1-10.

Enseñat-Soberanis, F., Frausto-Martínez, O. and Gándara Vázquez, M. (2019), “A visitor flow management process for touristified archeological sites", Journal of Heritage Tourism, Vol. 14 No. 4, pp. 340-357.

EventMB (2017), "11 Ways to Drive Traffic to the Trade Show Floor", available at: https://www.eventmanagerblog.com/drive-traffic-trade-show-floor (Accessed 10 March 2019).

Fahmy, S. A., Alablani, B. A., and Abdelmaguid, T. F. (2014), "Shopping center design using a facility layout assignment approach", in The $9^{\text {th }}$ International Conference on Informatics and Systems (INFOS2014), Cairo 15-17 December 2014, Cairo University, Cairo, pp. 1-7.

Fincher, S. and Tenenberg, J. (2005), „Making sense of card sorting data”, Expert Systems, Vol. 22 No. 3, pp. 8993.

Fitch, R. and Knobel, L. (1990), Fitch on Retail Design, Phaidon, Oxford.

Flick, U. (2009) An introduction to qualitative research, $4^{\text {th }}$ edition, Sage Publications, London.

Fox, D., Gouthro, M. B., Morakabati, Y. and Brackstone, J. (2014), Doing events research: from theory to practice, Routledge, London.

Frost, W. and Laing, J. (2018), Exhibitions, Trade Fairs and Industrial Events, Routledge, Abingdon.

Granbois, D. H. (1968), “Improving the Study of Customer In-store Behavior”, Journal of Marketing, Vol. 32 , pp. 28-33.

Graneheim, U. H., Lindgren, B. M. and Lundman, B. (2017), "Methodological challenges in qualitative content analysis: A discussion paper”, Nurse education today, Vol. 56, pp. 29-34.

Hart, M. (2014), "How to Drive Attendees to the Show Floor", available at: http://w"ww.smithbucklin.com/news/how-to-drive-attendees-to-the-show-floor/ (accessed 10 March 2019).

Hillier, B., Penn, A., Hanson, J., Grajewski, T. and Xu, J. (1993), "Natural movement: or, configuration and attraction in urban pedestrian movement", Environment and Planning B: Planning and Design, Vol. 20, pp. 29-66.

Hughes, P. (2010), Exhibition Design, Laurence King Publishing, London.

Johnson, J. C. and Weller, S. C. (2001), "Elicitation Techniques for Interviewing", in Gubrium, J. F. and Holstein, J. A. (Eds.), Handbook of Interview Research, Sage Publications, London, pp. 491-514.

Kijewski, V., Yoon, E. and Young, G. (1993), "How exhibitors select trade shows", Industrial marketing management, Vol. 22 No. 4, pp. 287-298.

Kitchen, E. (2017), "What is the value of networking? An examination of trade show attendee outcomes", Journal of Convention \& Event Tourism, Vol. 18 No. 3, pp. 191-204.

Klein, H.-J. (1993), “Tracking visitor circulation in museum settings”, Environment and Behavior, Vol. 25 No. 6, pp. $782-800$.

Lee, H. and Lee, J.S. (2017), “An exploratory study of factors that exhibition organizers look for when selecting convention and exhibition centers", Journal of Travel \& Tourism Marketing, Vol. 34 No. 8, pp. 1001-1017.

Lee, M. J. and Kang, Y. S. (2014), "Subject areas and future research agendas in exhibition research: Exhibitors' perspectives", Event Management, Vol. 18 No. 2, pp. 185-194.

Lee, M. J., Yeung, S. and Dewald, B. (2010), “An exploratory study examining the determinants of attendance motivations as perceived by attendees at Hong Kong exhibitions", Journal of Convention \& Event Tourism, Vol. 11 No. 3, pp. 195-208.

Lee, M.J. and Lee, S. (2014) 'Subject areas and future research agendas in exhibition research: visitors' and organizers' perspectives”, Event Management, Vol. 18 No. 3, pp. 377-386.

Levy, M. and Weitz, B. A. (2009), Retailing Management, $7^{\text {th }}$ edition, McGraw-Hill, New York.

Lin, C. T. and Lin, C. W. (2013), "Exhibitor perspectives of exhibition service quality", Journal of Convention \& Event Tourism, Vol. 14, No. 4, pp. 293-308.

Lin, Y., Jiang, J. and Kerstetter, D. (2018), “A three-component framework for trade show performance evaluation”, Journal of Hospitality \& Tourism Research, Vol. 42 No. 6, pp. 855-879.

Lincoln, Y. S. and Guba, E. G. (1985), Naturalistic inquiry, Sage, London.

Mason, J. (2002), Qualitative researching, $2^{\text {nd }}$ edition, Sage Publications, London. 
McMillin, D. (2017), “Troubling Numbers for the Trade Show Industry", available at: https://www.pcma.org/troubling-numbers-for-the-trade-show-industry/ (accessed 11 March 2019).

Melton, A. W. (1935), "Problems of installation in museums of art", Publications of the American Association of Museums, Vol. 14, pp. 253-269.

Morgan, T. (2011), Visual merchandising, $2^{\text {nd }}$ edition, Laurence King, London.

Muskat, B. and Deery, M. (2017), "Knowledge transfer and organizational memory. An events perspective", Event Management, Vol. 21, pp. 431-447.

Ngyuen, T. (2020), "Pop-up or Permanent? The Case of the Mardi Gras Museum", in Adair, J. G. and Levin, A. K. (Eds.), Museums, Sexuality, and Gender Activism, Routledge, London, Chapter 7.

Niroo, F. and Van Winkle, C. (2019), Exploring the Culinary Experiences of Diners at Pop-up Restaurants, in 2019 TTRA Canada Chapter Conference, Saskatoon, Saskatchewan, September 18 to 20, 2019

Parsons, J., Gokey, C. and Thornton, M. (2013), "Indicators of Inputs, Activities, Outputs, Outcomes and Impacts in Security and Justice Programming”, available at: https://assets.publishing.service.gov.uk/government/uploads/system/uploads/attachment_data/file/304626/I ndicators.pdf (accessed 4 February 2019).

Pett, E. (2015), "Tourists, Vandals and Pilgrims: A Study of Participant Responses to the Gromit Unleashed Public Art Trail in Bristol, 2013”, in Thorsen, E., Savigny, H., Alexander, J. and Jackson, D. (Eds.), Media, Margins and Popular Culture, Palgrave Macmillan, London, pp. 169-187.

Punch, S. (2002) "Interviewing Strategies with Young People: The 'Secret Box', Stimulus Material and Taskbased Activities", Children \& Society Volume, Vol. 16, pp. 45-56.

Qi, H., Smith, K. A., Yeoman, I. and Goh, S. (2018), "Exhibitor retention at an industry exhibition: The case of AgroChemEx in China", Journal of Convention \& Event Tourism, Vol. 19 No. 1, pp. 44-62.

Rinallo, D., Borghini, S. and Golfetto, F. (2010), "Exploring visitor experiences at trade shows", Journal of Business \& Industrial Marketing, Vol. 25 No. 4, pp. 249-258.

Rittichainuwat, B. and Mair, J. (2012), "Visitor attendance motivations at consumer travel exhibitions", Tourism Management, Vol. 33 No. 5, pp. 1236-1244.

Robillard, D. A. (1982), Public Space Design in Museum. Thesis (Master of Architecture). University of Wisconsin, Milwaukee, available at: https://dc.uwm.edu/cgi/viewcontent.cgi?article=1015\&context=caupr_mono (accessed: 27 November 2018).

Rossen, P. J. and Seringhaus, F. H. R. (1995), "Visitor and Exhibitor Interaction at Industrial Trade Fairs", Journal of Business Research, Vol. 32, pp. 81-90.

Schwartz, L. (2007), “10 Tips to Boost Exhibit Hall Traffic”, Medical Meetings, Vol. 34 No. 8, p. 22.

Scott, N. K. (1989), Shopping Centre Design, E \& FN Spon, London.

Shanmugam, R. (2013), “Anchor-store quality in malls: an economic analysis”, International Journal of Retail \& Distribution Management, Vol. 41 No. 2, pp. 90-112.

Smith, E. A. (2001), "The role of tacit and explicit knowledge in the workplace", Journal of Knowledge Management, Vol. 5 No. 4, pp. 311-321.

Smith, T. M., Hama, K. and Smith, P. M. (2003), "The effect of successful trade show attendance on future show interest: Exploring Japanese attendee perspectives of domestic and offshore international events", Journal of Business \& Industrial Marketing, Vol. 18 No. 4/5, pp. 403-418.

Sorensen, H. (2003), “The Science of Shopping”, Marketing Research, Fall 2003, pp. 30-35.

Sorensen, H. (2009), Inside the Mind of the Shopper - The Science of Retailing, Pearson, New Jersey.

Stephens, N. (2010) "Collecting Data from Elites and Ultra Elites: Telephone and Face-to-Face Interviews with Macroeconomists", in Atkinson, P. and Delamont, S. (Eds.), SAGE qualitative research methods, SAGE, London, pp. 203-216.

Tafesse, W. (2014), “Understanding how resource deployment strategies influence trade show organizers' performance effectiveness”, European Journal of Marketing, Vol. 48 No. 5/6, pp. 1009-1025.

Tafesse, W. and Skallerud, K. (2017), "A systematic review of the trade show marketing literature: 1980-2014", Industrial Marketing Management, Vol. 63, pp. 18-30.

Underhill, P. (2000), Why we buy: The science of shopping, Texere, London.

Uotila, V. and Skogster, P. (2007), "Space management in DIY store analysing consumer shopping paths with data-tracking devices", Facilities, Vol. 25 No. 9/10, pp. 363-374.

Vaid, J., Kesharwani, S. and Dubey, A. K. (2016), "A Study of MICE Tourism Dynamics in Auto Expo 2016”, Journal of Enterprise Information System, Vol. 8 No. 4, pp. 71-78. 
Wang, Y., Moyle, B., Whitford, M. and Wynn-Moylan, P. (2014), "Customer relationship management in the exhibition industry in China: An exploration into the critical success factors and inhibitors", Journal of China Tourism Research, Vol. 10 No. 3, pp. 292-322.

Warnaby, G. and Shi, C. (2019), "Changing customer behaviour: Changing retailer response? The potential for pop-up retailing”, Journal of Customer Behaviour, Vol. 18 No. 1, pp. 7-16.

Weidenfeld, A. and Leask, A. (2013), "Exploring the relationship between visitor attractions and events: definitions and management factors", Current Issues in Tourism, Vol. 16 No. 6, pp. 552-569.

Whitfield, J. and Webber, D. J. (2011), “Which exhibition attributes create repeat visitation?”, International Journal of Hospitality Management, Vol. 30, pp. 439-447.

Yalowitz, S. S. and Bronnenkant, K. (2009), “Timing and Tracking: Unlocking Visitor Behavior”, Visitor Studies, Vol. 12 No. 1, pp. 47-64.

Yi, X., Fu, X., Jin, W. and Okumus, F. (2018), "Constructing a model of exhibition attachment: Motivation, attachment, and loyalty”, Tourism Management, Vol. 65, pp. 224-236.

Y1lmaszsoy, A. C. (2005), Visitor Behaviour in Museum Environments: An Analysis of Visitor Circulation Patterns in Sadberk Hanim Museum. Thesis (Master of Fine Arts), Bilkent University, available at: http://www.thesis.bilkent.edu.tr/0003007.pdf (accessed 27 November 2018).

Zhang, Y., Li, X. R. and Su, Q. (2017), "Does spatial layout matter to theme park tourism carrying capacity?", Tourism Management, Vol. 61, pp. 82-95.

Zhou, Y. (2016), "6 Tips to Drive More Traffic to Exhibitors Booths", available at: https://helloendless.com/6tips-drive-traffic-to-exhibitors-booths/ (accessed 10 March 2019).

Zubiaga, M., Izkara, J. L., Gandini, A., Alonso, I. and Saralegui, U. (2019), “Towards Smarter Management in Historic Centres Through Visitor-Flow Monitoring”, Sustainability, Vol. 11 No. 7254, pp. 1-23. 